\title{
ЗНАЧЕНИЕ МЕЖДУНАРОДНЫХ НОРМ СОЦИАЛЬНОГО ОБЕСПЕЧЕНИЯ В РЕШЕНИИ ВОПРОСА БЕДНОСТИ
}

\section{THE IMPORTANCE OF INTERNATIONAL SOCIAL SECURITY STANDARDS IN ADDRESSING THE ISSUE OF POVERTY}

Yu. Izvarina

Summary. The article examines the main risks of the social sphere, which are enshrined in international acts, and are reflected in the provisions of the law of the Russian Federation on ensuring social direction.it is noted that the range of individuals who are subject to social protection from the country in the event of social risks is broader than provided for in international law. The role of the ILO Convention NNo. 102 "on minimum standards of social security" in establishing universal coverage and favorable conditions for granting the right to social protection in a broad sense is shown. Attention is drawn to the need to create "minimum standards" for the level of social protection at the legislative level, taking into account the requirements of international social security law, which will be a preventive strategy designed to reduce the risk of social instability in the future.

Keywords: poverty, social protection and security, labor market.

\author{
Изварина Юлия Юрьевна \\ Старший преподаватель, ФГБОУ ВО “Саратовская \\ государственная юридическая академия" \\ caramelk@yandex.ru
}

Аннотация. В статье исследуются основные риски социальной сферы, которые закреплены в международных актах, и отобразились в положениях права РФ об обеспечении социального направления; обращено внимание, что круг физических лиц, которые подлежат социальной защите со стороны страны при наступлении рисков социального характера, шире предусмотренного в нормах международного права. Показана роль Конвенции МОТ № 102 "0 минимальных нормах социального обеспечения" в установлении универсального охвата и благоприятных условий предоставления права на социальную защиту в широком смысле. Обращено внимание на необходимость формирования "минимальных стандартов" уровня социальной защиты на законодательном уровне, с учетом требований норм международного права социального обеспечения, что будет являться профилактической стратегией, призванной сократить риск социальной нестабильности в будущем.

Ключевые слова: бедность, социальная защита и обеспечение, рынок труда.
C пецифическое влияние на общественную жизнь оказывают экономические кризисы последних лет во всем мире, которые вносят изменения в строительство политической и экономической повестки страны, сдерживают улучшение условий поддержки физических лиц социального характера.

В Докладе о социальной защите в мире 2014/15 указано, что связь финансовых рынков и рынков труда во всем мире формирует новые вопросы для развития защиты и справедливости социального характера. Кризис экономики по всему миру поставил правительства большинства государств перед нуждой пересмотреть политику финансирования сферы социального характера и принять меры, которые направлены на стабилизацию финансового и прочих экономических секторов [1, с. 52-57].

Большое внимание обращается на то, что для формирования приличного уровня обеспечения социального характера системы национального права должны быть эффективными и такими, которые способны поддерживать гарантии социального характера на определенном уровне, независимо от финансового или кризиса экономики. Поддержка социального характера выступает определенным стимулом для активной деятельности трудового характера, расширяет участие людей на трудовом рынке, ведет к росту производительности. Система гарантий социального характера должна ускорять развитие экономики и смягчать действие рисков финансовой сферы.

Сильно возрастает роль стандартов социального обеспечения международного характера как ориентира для политики в социальной сферы и развития системы обеспечения социального направления РФ. В этом качестве стандарты международного характера могут указывать на реформирование или пересмотр системы национального характера обеспечения социальной сферы, являться стабилизатором отношений социального характера во время спада экономики или кризиса [2, с. 140].

Система гарантий государственной сферы, кроме формирования целевых источников финансов, должна включать кроме этого:

- доступ к базовым услугам здравоохранения, учитывая охрану материнства;

- основной уровень дохода для детей, который может быть гарантирован; 
- основной уровень дохода для физических лиц трудоспособного возраста, которые не получают достаточный доход, в случае болезни, безработицы, беременности и родов, инвалидности;

- основной уровень дохода для пожилых физических лиц [3, с. 41].

Сегодня можно констатировать, что основные риски социальной сферы, которые закреплены в международных актах, отобразились в положениях права РФ об обеспечении социального направления; круг физических лиц, которые подлежат социальной защите со стороны страны при наступлении рисков социального характера, шире предусмотренного в нормах международного права. Список видов помощи со стороны страны в России по каждому риску социального характера соответствует положениям Конвенции МОТ № 102. Объем и размер социальных выплат в форме денег до недавнего времени не соответствовал международным стандартам во всех случаях (например, уровень замещения заработка физического лица, которое было застраховано в силу наступления страхового случая ниже закреплённого в положениях Конвенции МОТ № 102). С ратификацией Конвенции МОТ № 102 в 2018 году РФ согласилась с принятием социальных стандартов минимального уровня, которые установлены на международном уровне [4].

Анализируя содержания стандартов и соответствия таким стандартам системы обеспечения социального характера России, можно сделать вывод о том, что сегодня важно строго учитывать при формировании системы обеспечения социального характера, как социальной и экономической системы, так и системы социально-обеспечительных норм права, правового принципа, как сочетание единства и разделения в правовом регулировании общественных правоотношении [1, с. 52-57].

Важнейшей задачей и приоритетом власти по отношению к установлению стандартов минимума - равномерное распределение денег между регионами, которое способствует сокращению разделения социального характера, преодолению бедности и выравниванию пространства социального характера. Такая цель - приоритетное направление развития защиты права от бедности не только в России, но и в международном контексте.

Стоит отметить еще одно важное направление защиты права от бедности. Россия имеет важную задачу разделить меры защиты социального характера бедных граждан, учитывая разделение бедности в зависимости от области ее воздействия на социальную и экономическую. Социальная бедность может быть распространена на определенные категории граждан в социальном контексте (престарелых, инвалидов, многодетных) и мо- жет быть уменьшена и полностью ликвидирована через средства обеспечения социального характера [5, с. 768].

В докладе МОТ «Социальное обеспечение на горизонте 2000 г.» была отмечена система борьбы с бедностью, которая используется по сей день большей частью организаций международного характера (Совет Европы, ОЭСР): на сегодняшний день рекомендовано выплачивать бедным минимальный денежный доход - пособие, которое должно быть утверждено в пределах усиления механизмов солидарности национального характера и помощи социального характера при сохранении систем социального обеспечения, которые действуют сегодня [6, с. 180].

В тоже время, вопросы обеспечения уровня прибыли (денег к существованию) шире термина проблем социального обеспечения нетрудоспособных. Во всем мире для трудоспособного населения главной основой доходов, средством нереализации бедности, являются виды занятости, разрешенные законодательством, деятельность трудового характера.

МОТ считает, что основной целью стратегии борьбы с бедностью населения, которое является трудоспособным, может стать стимулирование трудовой деятельности, которая является оплачиваемой, когда защищены права, а защита социального характера распространяется на всех работающих. В докладе Генерального директора МБТ «Обеспечение дохода и социальная защита в меняющемся мире» было прописано, что «для гарантированности доходов необходима: экономическая политика, которая благоприятно относится к трудовой занятости; образование и подготовка профессионального характера; охрана здоровья; нормы права о труде» [7].

Из-за существенных изменений на трудовом рынке масштабной в России является экономическая бедность. В сфере трудового права, право на защиту от бедности связано с правом на справедливое вознаграждение (ст. 4 Европейской социальной Хартии). Вопреки мнению С.А. Горшковой, это право не воплотилось в должной мере в предложениях законодательства РФ [8].

Европейский комитет по социальным правам на базе Европейской социальной Хартии прописал, что доход справедливого размера не может быть существенно ниже средней заработной платы в государстве, менее 60 процентов. Зарплата должна быть выше границы бедности. Иначе зарплата не выполняет воспроизводственную и стимулирующую задачи. В США, например, минимальная заработная плата должна обеспечивать жизненный уровень для 3 членов семьи работающего физического лица выше границы бедности. В России же 1/3 трудоустроенных получают денежные выплаты ниже миниму- 
ма, который сформирован страной. Чтобы уменьшить уровень экономической бедности минимальную зарплату нужно сформировать на уровне реального минимума потребления, или социального минимума [3, с. 41].

Рассматривая преобразования экономического характера, которые необходимо применять РФ для преодоления бедности экономического характера, можно отметить, что стране необходимо наращивать потенциал регионального производства и экономики, рассмотреть направления, которые в приоритете и привлекать инвесторов в регионы. Необходимо учреждать программы для развития сельского населения, жителей малых городов, среди которых 60\% имеют прибыль натурального характера, не превышающей прожиточный минимум. Страна должна помогать развивать аграрный сектор, что формирует для депрессивных регионов возможность увеличить число трудовых мест и уменьшить уровень безработицу.

Бедность - многоаспектная обширная проблема, с которой необходимо бороться с помощью экономических реформ, а не только социальных. Изменения в социальной политике должны происходить в соответствии с экономическими изменениями. Экономика рыночного характера обеспечит мощную мотивацию в виде конкурентной борьбы, в которой выживет сильнейший; станет логичным, что невозможно развить богатое государство бедными гражданами [9].

Подытоживая вышеизложенное, следует констатировать, что бедность сегодня является проблемой номер один как на международном уровне, так и в Российской Федерации. Именно поэтому, международные акты, которые принимаются в последние 20-30 лет направлены на искоренение и уменьшение проявления бедности в мире, в особенности в самых бедных странах.

В тоже время, для всех стран без исключения важным является построение такой системы защиты права от бедности, то есть такой системы защиты граждан социального характера в случае возникновения социального риска в виде бедности не ниже минимальных международных стандартов. Российская Федерация сделала в этом отношении за последние 5 лет множество важных шагов, таких как ратификация Европейской социальной Хартии и Конвенции МОТ № 120. Это стало важным направлением в борьбе с бедностью. Также стоит подчеркнуть, что в некоторых аспектах социальная защита в РФ, которая установлена нормами социального законодательства превышает минимальный уровень социальной защиты, предложенный международными правовыми нормами. Это не является запрещенным, поскольку не ухудшает, а улучшает уровень жизни людей $[10$, c. 196$]$.

Важно отметить, что бедность как феномен можно разделить на социальную или экономическую. Если социальную бедность можно уменьшить путем увеличения социальных выплат, то экономическая бедность связана с уровнем дохода трудоспособного населения. С такой бедностью можно бороться исключительно методами экономического оживления страны в целом.

\section{ЛИТЕРАТУРА}

1. Парягина 0. А. Право на защиту от бедности. Российский ракурс. Сибирский юридический вестник. — 2004.— № 2. - C. 52-57.

2. Челнокова Г. Б. Социальное законодательство, направленное на защиту от бедности в России: проблемы теории и практики: дис. ... канд. юрид. наук. M. - 2003. - $140 \mathrm{c}$.

3. Байгереев В. Бедность и политика адресной социальной помощи малоимущим семьям // Человек и труд. 2001. № 1. С. 41.

4. Воронкова О. В. Государственная политика регулирования уровня бедности населения в России и других странах // TERRA ECONOMICUS (Экономический вестник Ростовского государственного университета). — 2009.— Том 7.— № 2.

5. Баглай М. В. Конституционное право Российской Федерации // учебник. — 12-е изд., изм. и доп. — Москва: Норма: ИНФРА-М. — 2017. — 768 с.

6. Агарков Р. В. Бедность: феномен, методы исследования и стратегия преодоления: дис. ... канд. соц. наук.— М.— 2001.—180 с.

7. Федеральный закон «0 внесении изменений в отдельные законодательные акты Российской Федерации в части учета и совершенствования предоставления мер социальной поддержки исходя из обязанности соблюдения принципа адресности и применения критериев нуждаемости» 0 2 29.12 .2015 № 388 Ф3 [Электронный ресурc] http://www.consultant.ru/document/cons_doc_LAW_191260/ (дата обращения:03.02.2020).

8. Горшкова С. А. Европейские нормы по правам человека и усилия России по их соблюдению // Журнал российского права.— 2011.— № 11.

9. Трудовой Кодекс Российской Федерации от 30.12.2001 № 197-Ф3. [Электронный ресурc]. URL. http://www.consultant.ru/document/cons_doc_LAW_34683/ (дата обращения: 02.02.2020).

10. Нечаева Е. Г. Социальное государство. Правовое понимание и практика: дис. ... канд. юрид. наук. — М._ 2007.— 196 с. 